\title{
Hygienic-sanitary quality of ready-to-eat salmon sashimi (Salmo Salar)
}

\author{
Qualidade higiênico-sanitária de sashimi de salmão (Salmo salar) pronto para o consumo \\ Calidad higiénico-sanitaria del sashimi de salmón (Salmo salar) listo para consumir
}

Received: 09/22/2021 | Reviewed: 09/28/2021 | Accept: 09/29/2021| Published: 10/01/2021

\author{
Iara Oliveira Arruda \\ ORCID: https://orcid.org/0000-0001-8273-5796 \\ Instituto Federal de Educação, Ciência e Tecnologia de Mato Grosso, Brazil \\ E-mail: iaraoliveiraarruda@gmail.com \\ Talitha Maria Porfírio \\ ORCID: https://orcid.org/0000-0001-8741-9143 \\ Instituto Federal de Educação, Ciência e Tecnologia de Mato Grosso, Brazil \\ E-mail: talithamari@hotmail.com \\ Edgar Nascimento \\ ORCID: https://orcid.org/0000-0002-7825-1948 \\ Instituto Federal de Educação, Ciência e Tecnologia de Mato Grosso, Brazil \\ E-mail: edgar.nascimento@blv.ifmt.edu.br \\ Demétrio de Abreu Sousa \\ ORCID: https://orcid.org/0000-0003-0465-6034 \\ Instituto Federal de Educação, Ciência e Tecnologia de Mato Grosso, Brazil \\ E-mail: demetrio.sousa@blv.ifmt.edu.br \\ Daniel Oster Ritter \\ ORCID: https://orcid.org/0000-0003-2737-841X \\ Instituto Federal de Educação, Ciência e Tecnologia de Mato Grosso, Brazil \\ E-mail: daniel.ritter@blv.ifmt.edu.br \\ Marilu Lanzarin \\ ORCID: https://orcid.org/0000-0001-9838-4011 \\ Instituto Federal de Educação, Ciência e Tecnologia de Mato Grosso, Brazil \\ E-mail: marilu.lanzarin@blv.ifmt.edu.br
}

\begin{abstract}
Fifty sashimi samples from 5 restaurants were characterized for enumeration of Aerobic Psychrotrophic Heterotrophic Bacteria (APHB) and Aerobic Mesophilic Heterotrophic Bacteria (AMHB), Enterobacteriaceae, coliforms at $45^{\circ} \mathrm{C}$ (thermotolerant coliforms), coagulase-positive Staphylococci, presence of Vibrio parahaemolyticus and Salmonella sp., and determination of hydrogen potential $(\mathrm{pH})$ and total volatile basic nitrogen (TVB-N). The bacterial isolates were evaluated for their resistance profile to the antimicrobial agents Penicillin, Ampicillin, Cefoxitin, Cefotaxime, Amikacin, Gentamicin, Tetracycline, and Trimethropim-sulfamethoxazole. The results showed that APHB, AMHB and coagulase-positive Staphylococci counts and the determination of $\mathrm{pH}$ and TVB-N were in accordance with national and international standards adopted as safe limits for consumption. In contrast, the Enterobacteriaceae and thermotolerant coliforms counts and presence of Salmonella sp. and V. parahaemolyticus were in disagreement with those standards, raising concern about the hygienic-sanitary quality of sashimi. The Staphylococcus aureus and V. parahaemolyticus isolates showed resistance to Penicillin, Ampicillin, Cefoxitin, Cefotaxime, Tetracycline, Gentamicin, and Amikacin, while the Salmonella sp. isolate showed no resistance to all the antimicrobial agents studied. The results showed that $48 \%$ of the samples were fit for consumption while $52 \%$ had unsatisfactory hygienicsanitary quality for the parameters evaluated.
\end{abstract}

Keywords: Brazil; Raw fish; Food security; Consumption; Bacterium; Antibiotics.

\section{Resumo}

Cinquenta amostras de sashimi de 5 restaurantes foram caracterizadas quanto à contagem de Bactérias Heterotróficas Psicrotróficas Aeróbicas (APHB) e Bactérias Heterotróficas Mesofílicas Aeróbicas (AMHB), Enterobacteriaceae, Coliformes a $45^{\circ} \mathrm{C}$ (Coliformes Termotolerantes), Estafilococos coagulase positiva e presença de Vibrio parahaemolyticus e Salmonella sp. e determinação do potencial de hidrogênio $(\mathrm{pH})$ e nitrogênio básico volátil total (TVB-N). Foi avaliado o perfil de resistência dos isolados bacterianos aos agentes antimicrobianos penicilina, ampicilina, cefoxitina, cefotaxima, amicacina, gentamicina, tetraciclina e trimetripim-sulfametoxazol. Os resultados mostraram que as contagens de APHB, AMHB e estafilococos coagulase positiva e os valores das determinações de pH e TVB-N correspondem (estão de acordo) com as normas nacionais e internacionais adotadas como limites seguros de consumo. Em contraste, a contagem de Enterobacteriaceaes e coliformes termotolerantes e a presença de Salmonella sp. e V. parahaemolyticus não corresponde ao que estabelece (discordam) com essas normas, o que suscita preocupações quanto à qualidade higiênico-sanitária do sashimi. Os isolados de Staphylococcus aureus e V. 
parahaemolyticus mostraram resistência à penicilina, ampicilina, cefoxitina, cefotaxima, tetraciclina, gentamicina e amicacina, enquanto Salmonella sp. o isolado não apresentou resistência a todos os antimicrobianos estudados. Os resultados mostraram que $48 \%$ das amostras eram adequadas para consumo enquanto $52 \%$ apresentavam qualidade higiênico-sanitária insatisfatória para os parâmetros avaliados.

Palavras-chave: Brasil; Peixe cru; Alimento seguro; Consumo; Bactéria; Antibióticos.

\section{Resumen}

Cincuenta muestras de sashimi de 5 restaurantes fueron caracterizadas para el recuento de Bacterias Heterotróficas Psicrotróficas Aeróbicas (APHB) y Bacterias Heterotróficas Mesofílicas Aerobias (AMHB), Enterobacteriaceae, Coliformes a $45^{\circ} \mathrm{C}$ (Coliformes termotolerantes), Estafilococos coagulasa positivos y presencia de Salmonella sp. y Vibrio parahaemolyticus y determinación del potencial de hidrógeno $(\mathrm{pH})$ y nitrógeno básico volátil total (TVB-N). Se evaluó el perfil de resistencia de los aislados bacterianos a los agentes antimicrobianos penicilina, ampicilina, cefoxitina, cefotaxima, amikacina, gentamicina, tetraciclina y trimetripim-sulfametoxazol. Los resultados mostraron que los recuentos de APHB, AMHB e estafilococos coagulasa positivos y los valores de las determinaciones de $\mathrm{pH}$ y TVB-N se corresponden (estaban de acuerdo) con los estándares nacionales e internacionales adoptados como límites seguros para o consumo. Ao contraste, o recuento de Enterobacteriaceaes e coliformes termotolerantes e a presença de Salmonella sp. e V. parahaemolyticus não se corresponde com o que estabelece (estaban em desacuerdo) com esas normas, lo que suscitaba preocupação por la calidad higiénico-sanitaria del sashimi. Los aislados de Staphylococcus aureus y $V$. parahaemolyticus mostraron resistencia a penicilina, ampicilina, cefoxitina, cefotaxima, tetraciclina, gentamicina y amikacina, mientras que Salmonella sp. el aislado no mostró resistencia a todos los agentes antimicrobianos estudiados. Los resultados arrojaron que el $48 \%$ de las muestras eran aptas para el consumo mientras que el 52\% presentaba una calidad higiénico-sanitaria insatisfactoria para los parámetros evaluados.

Palabras clave: Brasil; Pescado crudo; Seguridad alimentaria; Consumo; Bacteria; Antibióticos.

\section{Introduction}

The general public's view of the modern diet and human health has led to new eating habits in recent years. Fish consumption has increased worldwide, due to its high nutritional value and intrinsic characteristics. However, this food matrix is very susceptible to microbiological contamination, requiring care from capture to consumption, such as hygiene, cold storage, and heat treatment.

Although an adequate cooking process represents food safety, the globalization of Japanese cuisine has led to the consumption of fish in the form of sashimi, which consists of thin slices of raw fish served with sauces, and not subjected to cooking steps. Therefore, it is essential to apply quality control tools, such as the adoption of good manufacturing practices, with temperature control in all stages after the capture and use of ice made with treated water ${ }^{50}$ for ensuring hygienic-sanitary quality.

Food safety, one of the general food hygiene principles of the Codex Alimentarius, is defined as the assurance that food will not cause harm to the consumer during preparation and consumption (FAO, 1998). Failures in the hygienic-sanitary aspects can contribute to foodborne illness occurrences, with risks to consumers' health (WHO, 2018; Brasil, 2019). In this context, raw fish stand out for being more susceptible to deterioration and microbial contamination.

National and international microbiological guidelines have been adopted to ensure food safety and quality, including those of the National Health Surveillance Agency (ANVISA) (Brasil, 2001), International Commission on Microbiological Specifications for Foods (ICMSF, 1986), Center for Food Safety (CFS, 2014) and Ryser and Schuman (2015), as well as the Regulation of the Industrial and Sanitary Inspection of Products of Animal Origin (RIISPOA), which has established values for the hydrogen potential $(\mathrm{pH})$ and total volatile basic nitrogen of fresh fish (Brasil, 2017).

The emergence of bacteria resistant to antimicrobial agents is another trouble related to fish consumption, which has been a concern of international health agencies and several interrelated institutions, in addition to consumers, once antimicrobial resistance is one of the most serious global public health threats. The resistance of bacteria increases in places with intense transit, such as hospitals, food animal production and aquaculture (Cabello et al., 2016; Cabello e Godfrey, 2016; Venter, Henning e Begg, 2017). 
Therefore, this study aimed to investigate the hygienic-sanitary quality of salmon (Salmo salar) sashimi ready for consumption in the city of Cuiaba, Mato Grosso, Brazil, through the microbiological, physicochemical, and antimicrobial resistance profile, and the potential risks to consumers' health.

\section{Methodology}

A survey of all Japanese cuisine restaurants in the city of Cuiaba, Mato Grosso, Brazil $(n=28)$ was carried out. Five restaurants were randomly selected for sample collection, four of which specialized in Japanese cuisine. The samples consisted of portions of approximately 200 grams of salmon sashimi, and 10 samples were collected in each restaurant (R1, R2, R3, R4, and R5), totaling 50 samples. The samples were ordered and taken from each restaurant at the beginning of the working day. The sashimi portions were packed in the packages offered by the establishment, which were immediately placed in a thermal box with ice packs to maintain the temperature during transport to the Food Microbiology Laboratory of the Federal Institute of Education, Science and Technology of Mato Grosso (IFMT) Cuiaba - Bela Vista Campus, for analysis. The time interval between collecting the samples and starting the analysis did not exceed one hour. This quantitative study used a completely randomized design (Pereira, 2018).

\subsection{Microbiological characterization}

The microbiological analyses consisted of the enumeration of Aerobic Psychrotrophic Heterotrophic Bacteria (APHB) (APHA 13.61: 2015), Aerobic Mesophilic Heterotrophic Bacteria (AMHB) (APHA 08: 2015), Enterobacteriaceae (APHA 9.62: 2015), Coliforms at $45^{\circ} \mathrm{C}$ (APHA: 2015 and APHA / AWA / WEF 9221: 2012), coagulase-positive Staphylococci (ISO 6888-1: 1999 Amd 1: 2003 and APHA 39.61: 2015), presence of Salmonella sp. (ISO 6579 method) and presence of Vibrio parahaemolyticus (APHA 40.62 / 40.63: 2015) (Silva et al., 2017). The microbiological assays were performed in triplicate, with the results expressed in Log CFU/g.

\subsection{Physicochemical characterization}

The samples were characterized for hydrogen potential $(\mathrm{pH})$ according to ISO 2917 (1999) with direct reading on bench $\mathrm{pH}$ and total volatile basic nitrogen (TVB-N) according to Brazil (1981), and the results expressed in mg TVB-N/100 g. All determinations were performed in triplicate.

\subsection{Antimicrobial resistance profile}

After biochemical confirmation (Silva et al., 2017), the bacterial strains isolated from salmon sashimi were identified and kept refrigerated until analysis. The antimicrobial resistance profile was performed according to the antibiotic disk diffusion method (Bauer et al., 1966).

In vitro antimicrobial susceptibility tests were performed according to the recommendations of the Clinical and Laboratory Standards Institute (CLSI, 2010, 2016, 2018). For that, 10 antimicrobial agents were used, as follows: Penicillin 10 $\mu \mathrm{g}$ - PEN; Ampicillin $10 \mu \mathrm{g}$ - AMP; Gentamicin $10 \mu \mathrm{g}$ - GEN; Oxacillin $1 \mu \mathrm{g}$ - OXA; Trimethropim: sulfamethoxazole (1:5 ratio) $25 \mu \mathrm{g}$ - TMP-SMX; Tetracycline $30 \mu \mathrm{g}$ - TET; Amikacin $30 \mu \mathrm{g}$ - AMI; Cefotaxime $30 \mu \mathrm{g}$ - CTX; and Cefoxitin $30 \mu \mathrm{g}$ CFO.

\subsection{Statistical analysis}

The results of the physicochemical and microbiological characterization were analyzed by analysis of variance (ANOVA) at a $5 \%$ level of significance $(\mathrm{p}<0.05)$. The Kolmogorov-Smirnov normality test was applied to all data. The normally distributed data were analyzed through a completely randomized design (CRD) using the Tukey’s test (pH, TVB-N, 
APHB, Enterobacteriaceae). The Kruskal-Wallis and the Wilcoxon mean comparison tests were applied to data that presented no normality (AMHB, coliforms at $45{ }^{\circ} \mathrm{C}$, coagulase-positive staphylococci). The microbiological counts (APHB, AMHB, Enterobacteriaceae, coliforms at $45{ }^{\circ} \mathrm{C}$, coagulase-positive staphylococci) were transformed into Log 10 by the statistical program. The chi-square test was used for the results of the presence of Salmonella sp. and Vibrio parahaemolyticus, to determine whether the results were homogeneous concerning the five restaurants. Principal Component Analysis (PCA) was also performed to correlate the physicochemical and microbiological data between restaurants, using a correlation matrix. To determine the hygienic-sanitary quality of the samples, the results were compared with legislation standards and international references, determining the number of satisfactory and unsatisfactory samples, in percentage. The statistical program $\mathrm{R}$ version 3.6.1 was used (R Core Team, 2019).

\section{Results and Discussion}

\subsection{Hygienic-sanitary quality}

APHB, also known as spoilage bacteria, grow in refrigerated products $\left(0-7^{\circ} \mathrm{C}\right)$ leading to food deterioration due to the activity of proteolytic and lipolytic enzymes (Lanzarin et al., 2011). Some authors have reported counts above 7, 4.59, and 6.18 Log CFU/g in sashimi (Muscolino et al., 2014, Miguéis et al., 2015, Miguéis et. al, 2016). In the present study, as shown in Table 1, R2 presented the lowest APHB count (3.43 Log CFU/g) (p <0.05), ranging from 2.76 to 4.90 Log CFU/g, while R1, R3, and R5 presented intermediate results ( $p>0.05$ ), with values ranging from 3.95 to 5.55 ; 3.96 to 5.53 ; and 3.64 to $5.90 \mathrm{Log}$ CFU/g, respectively. R4 had the highest APHB count (5.76 Log CFU/g) (p <0.05), ranging from 5.2 to 6.41 Log CFU/g. These results are lower than those found in the literature and satisfactory according to the ICMSF standard (1986), which has established a maximum count of $7 \mathrm{Log}$, showing little deteriorating activity.

The AMHB counts ranged from 4.69 to $5.52 ; 3.27$ to $4.27 ; 4.14$ to $4.74 ; 4.37$ to 5.32 ; and 4.81 to $5.40 \mathrm{Log}$ CFU/g for R1, R2, R3, R4, and R5, respectively, and the lowest count (Table 1) was observed for R2 with 3.69 Log CFU/g (p <0.05) while R1 and R5 presented the highest counts with values of 5.06 and $5.14 \mathrm{Log}$ CFU/g, respectively (p>0.05). These microorganisms are considered indicators of food quality, demonstrating hygienic conditions during the manufacturing process, in addition to contributing to the determination of the shelf life. The present counts were satisfactory, with microbial counts lower than $6 \log$ CFU/g, according to the classification of the Center for Food Safety (2014) and Ryser and Schuman (2015). Several authors have found different mesophilic bacteria counts in sushi and sashimi, with values of 5.5 Log CFU/g; 5.3 Log CFU/g; 5.11 Log CFU/g; and 7.0 Log CFU/g (Liang et al., 2016; Kim et al., 2016; Miguéis et al., 2015; Muscolino et al., 2014).

The enumeration of Enterobacteriaceae (ENT) ranged from 3.26 to $4.06 ; 0$ to $1.49 ; 1.49$ to $3.36 ; 3.20$ to 4.42 ; and 4.43 to $5.30 \mathrm{Log}$ CFU/g for R1, R2, R3, R4, and R5, respectively, with the lowest and highest counts observed for R2 and R5, with values of 0.43 and $4.76 \mathrm{Log}$ CFU/g, with significant differences between them ( $\mathrm{p}<0.05)$. The restaurants R1, R3, and R4 presented intermediate counts, with no differences between R1 and R4 ( $>0.05)$ (Table 1). Bacterial counts <2 Log are considered satisfactory, from 2 to $\leq 4$ Log are acceptable, and bacterial counts $>4$ Log are considered unsatisfactory (CFS, 2014). In this research, R1, R4, and R5 presented high contamination levels, with unsatisfactory results observed in $10 \%$, $40 \%$, and $100 \%$ of the samples, respectively, thus the samples were unsuitable for consumption and/or potentially dangerous to human health. Enterobacteriaceae can be indicative of hygienic conditions in manufacturing processes, as they can colonize environments with poor sanitation, and some strains are pathogenic and represent a risk to public health (SILVA et al. 2017). Studies with salmon and tuna sashimi found Enterobacteriaceae counts of 3.39; 3.43; and 3.25 Log CFU/g, respectively (Miguéis, et al., 2015; Miguéis, et al., 2016) corroborating the findings of this study. 
Table 1. Microbiological and physicochemical characterization of salmon (Salmo salar) sashimi ready for consumption in the city of Cuiaba, Mato Grosso, Brazil.

\begin{tabular}{llllllllll}
\hline \multicolumn{2}{l}{ Log 10 CFU / g mean \pm standard deviation } \\
\hline & $\mathrm{pH}$ & TVB-N & APHB & AMHB & ENT & COL & STA & SAL & VIB \\
$\mathbf{R 1}$ & $6.28 \pm$ & $17.71 \pm$ & $4.82 \pm$ & $5.06 \pm$ & $3.69 \pm$ & $3.49 \pm$ & $0^{\mathrm{b}}$ & Presence & Presence \\
& $0.04^{\mathrm{b}}$ & $1.78^{\mathrm{ab}}$ & $0.56^{\mathrm{b}}$ & $0.26^{\mathrm{a}}$ & $0.30^{\mathrm{b}}$ & $0.33^{\mathrm{a}}$ & & $(1 / 10)$ & $(6 / 10)$ \\
$\mathbf{R 2}$ & $6.24 \pm$ & $16.35 \pm$ & $3,43 \pm$ & $3,69 \pm$ & $0.43 \pm$ & $0.10 \pm$ & $0.13 \pm$ & Absence & Absence \\
& $0.03^{\mathrm{bc}}$ & $1.09^{\mathrm{b}}$ & $0.66^{\mathrm{c}}$ & $0.32^{\mathrm{d}}$ & $0.10^{\mathrm{d}}$ & $0.32^{\mathrm{c}}$ & $0.74^{\mathrm{b}}$ & & \\
$\mathbf{R 3}$ & $6.22 \pm$ & $16.61 \pm$ & $4.90 \pm$ & $4.45 \pm$ & $2.74 \pm$ & $0.28 \pm$ & $0.38 \pm$ & Absence & Absence \\
& $0.02^{\mathrm{c}}$ & $1.58^{\mathrm{b}}$ & $0.45^{\mathrm{b}}$ & $0.19^{\mathrm{c}}$ & $0.59^{\mathrm{c}}$ & $0.60^{\mathrm{c}}$ & $0.62^{\mathrm{b}}$ & & \\
$\mathbf{R 4}$ & $6.30 \pm$ & $17.47 \pm$ & $5.76 \pm$ & $4.79 \pm$ & $3.96 \pm$ & $0^{\mathrm{c}}$ & $0.13 \pm$ & Absence & Presence \\
& $0.04^{\mathrm{a}}$ & $2.40^{\mathrm{ab}}$ & $0.37^{\mathrm{a}}$ & $0.28^{\mathrm{b}}$ & $0.36^{\mathrm{b}}$ & & $0.41^{\mathrm{b}}$ & & $(5 / 10)$ \\
$\mathbf{R 5}$ & $6.28 \pm$ & $18.98 \pm$ & $5.05 \pm$ & $5.14 \pm$ & $4.76 \pm$ & $2.11 \pm$ & $1.38 \pm$ & Absence & Presence \\
& $0.01^{\mathrm{ab}}$ & $1.68^{\mathrm{a}}$ & $0.62^{\mathrm{b}}$ & $0.19^{\mathrm{a}}$ & $0.28^{\mathrm{a}}$ & $1.30^{\mathrm{b}}$ & $1.09^{\mathrm{a}}$ & & $(1 / 10)$ \\
\hline
\end{tabular}

ENT: Enterobacteriaceae, COL: coliforms at $45{ }^{\circ} \mathrm{C}$, STA: coagulase-positive staphylococci, SAL: Salmonella; VIB: Vibrio parahaemolyticus. Same letters in the same column indicate no difference at the 5\% significance level $(\mathrm{p}<0.05)$. Tukey`s test was used for pH, TVB-N, APHB, and ENT. Kruskal-Wallis test was used for AMHB, COL, and STA. The chi-square test was used for SAL and VIB.

Source: Authors (2021).

As can be seen in Table 1, the lowest thermotolerant coliforms (COL) counts were observed for R2, R3, and R4, with values of $0.10 ; 0.28$; and $0 \mathrm{Log} \mathrm{CFU} / \mathrm{g}$, respectively ( $\mathrm{p}>0.05$ ) (ranging from 0 to 1,0 to 1.51 , and $0 \mathrm{Log} \mathrm{CFU} / \mathrm{g}$, respectively). The highest count was found in R1 with 3.49 Log CFU/g (2.94 to $4.03 \mathrm{Log}$ CFU/g), followed by R5 with $2.11 \mathrm{Log}$ CFU/g (0 to $3.76 \mathrm{Log} C F U / g$ ) (p <0.05). All samples $(100 \%)$ from the restaurant R1 and half (50\%) of the samples from R5 had counts higher than those established by the Brazilian legislation (2 Log CFU/g) (Brasil, 2001), corroborating the results of Enterobacteriaceae and showing concern with hygienic-sanitary quality since this group of microorganisms may contain potentially pathogenic and FBD-causing strains. In this study, although Escherichia coli was not detected, other bacteria from the coliform group were detected, such as Enterobacter sp., Klebsiella sp., and Pantoea sp.

Regarding the enumeration of positive coagulase staphylococci (STA), all samples were classified as satisfactory, with counts lower than 3.69 Log CFU/g (Brasil, 2001), with the lowest values observed for R1, R2, R3, and R4, with 0; 0.13; $0.38 ; 0.13 \mathrm{Log}$ CFU/g, respectively ( $\mathrm{p}>0.05$ ) (Table 1) (counts ranging from $0 ; 0$ to $1.30 ; 0$ to 1.43 ; and 0 to $1.30 \mathrm{Log}$ CFU/g for R1, R2, R3, and R4, respectively). In contrast, the restaurant R5 presented the highest count, $1.38 \mathrm{Log}$ CFU/g, $(\mathrm{p}<0.05)$ (Table 1), ranging from 0 to $2.58 \mathrm{Log} \mathrm{CFU} / \mathrm{g}$. Although the samples presented satisfactory counts, this group of microorganisms stands out as is enterotoxins producers and the contamination may be due to the lack of hygiene during handling or processing since this bacterium is natural in the animal and human microbiota. From 2009 to 2018, this agent was considered one of the main bacteria responsible for foodborne outbreaks in Brazil, being the third etiological agent with 9.5\% of cases (Brasil, 2019). In the present study, Staphylococcus aureus, a species with great potential for toxin production, was found in the restaurants R2, R3, R4, and R5. Staphylococci are popularly identified in sashimi, with recent studies in Italy (Muscolino et al., 2014), Portugal (Miguéis et al., 2015; Miguéis et al., 2016) and Malaysia (Puah et al., 2017). They are also found in oysters, shrimp, sushi, and a variety of fresh marine fish in several countries such as Turkey (Onmaz et al., 2015), Switzerland (Boss et al., 2016), Iran (Arfatahery et al., 2016), and Denmark (Li et al., 2019).

The presence of Salmonella sp. in food is a worrying factor, as it is the main cause of food-borne illnesses with tens of millions of cases per year worldwide (WHO, 2018). In Brazil, from 2000 to 2017, 12,503 outbreaks were reported by etiologic agents, with 236,403 sick people registered with the Ministry of Health, and Salmonella sp. was the most common bacterial cause, with 30\% of cases (Brasil, 2018). As can be seen in Table 1, the presence of Salmonella sp. was detected in a sample from the restaurant R1, which is in disagreement with the legislation (Brasil, 2001) and considered inappropriate for human 
consumption, becoming an alert factor with potential pathogenic risk. Prevention requires care in all stages of the food chain, from production to consumption (WHO, 2018). Puah et al. (2017) found Salmonella enterica in $21.66 \%$ (13/60) of retail sashimi samples in Valley Klang, Malaysia, which was also observed by other authors in fresh fish in Nigeria (Beshiru et al., 2019), Jordan (Obdait e Salman, 2017) and Turkey (Onmaz et al., 2015).

Vibrio parahaemolyticus is a marine bacterium responsible for illness of gastroenteritis after consumption of raw, inadequately cooked, or croos-contamined seafood (Sakazaki, 2003). The present study found the presence of Vibrio parahaemolyticus in $24 \%$ of the samples studied, consisting of twelve samples ( 6 samples in R1, 5 samples in R4, and 1 sample in R5), which is of concern, as this bacterium is related to cases of gastroenteritis evolving to septicemia in immunocompromised individuals, even leading to death. The presence of this agent in the samples of this study may be due to the origin of the raw material, suggesting that it comes from contaminated water and different producers. Other Vibrio sp. species were also verified in this study, such as V. mimicus, V. metchnikovii, which serves as a warning for the occurrence of unknown pathogenic strains that can be risk factors associated with outbreaks (FDA, 2012). Some authors have reported Vibrio sp. in sashimi, with counts $\geq 2$ and $\geq 3$ Log CFU/g (Muscolino et al., 2015; Kim et al., 2016). V. parahaemolyticus has also been found in several fresh seafood worldwide, such as in Ecuador (Sperling et al., 2015), China (Xu et al., 2016), Vietnam (Vu et al., 2016), Poland (Lopatek et al., 2018), Brazil (Silva et al., 2018), and Korea (Kang et al., 2019, Ryu et al., 2019).

Some compounds are produced from bacterial metabolism and fish decomposition, which can be indicative of fish quality, such as total volatile basic nitrogen (TVB-N) and hydrogen potential (pH) (Gonçalves, 2011). For TVB-N, the results ranged from 14.56 to 20.22 ; 14.57 to $17.71 ; 14.70$ to $19.18 ; 13.88$ to 20.62 ; and 15.79 to $21.87 \mathrm{mg}$ of TVB-N/100g for R1, R2, R3, R4, and R5, respectively. The restaurants R2 and R3 had the lowest mean value, with 16.35 and $16.61 \mathrm{mg}$ TVB-N/100g, respectively, when compared to R5, which presented $18.98 \mathrm{mg}$ TVB-N/100g. The restaurants R1 and R4 presented TVB-N levels similar to those observed for the restaurants R2, R3, and R5 ( $p>0.05$ ). The determination of volatile basic nitrogen (TVB-N) are used to characterize the freshness of fish since the formation of nitrogen compounds results from the enzymatic and bacterial deterioration, forming products from the decomposition of the amino acids such as dimethylamine, trimethylamine, ethylamine, monomethylamine, ammonia, putrescine, cadaverine, and spermidine (Ogawa e Maia, 1999; Howgate, 2010; Nollet e Toldrá, 2010; Gonçalves, 2011). Therefore, the TVB-N levels can be indicative of fish conservation, especially regarding the stage of deterioration.

However, some species can present higher levels of these compounds, even though they are not under the decomposition process, such as the Salmo salar species for example, which has a higher level up to $35 \mathrm{mg} \mathrm{N} / 100 \mathrm{~g}$, according to the Annex I of the European Communities (1995). For the Brazilian legislation, fish, in general, must have total volatile bases levels lower than $30 \mathrm{mg}$ of $\mathrm{N} / 100 \mathrm{~g}$ of muscle tissue (Brasil, 2017). All samples analyzed in this study met this parameter.

The $\mathrm{pH}$ of the samples ranged from 6.20 to $6.36 ; 6.19$ to $6.27 ; 6.18$ to $6.25 ; 6.22$ to 6.35 ; and 6.25 to 6.30 , for R1, R2, R3, R4, and R5, respectively, with the lowest $\mathrm{pH}$ found in the restaurants R3 and R4 (6.22 and 6.24, respectively), and the highest $\mathrm{pH}$ in the restaurants $\mathrm{R} 1, \mathrm{R} 2$, and $\mathrm{R} 5(6.28,6.30$, and 6.28 , respectively) as shown in Table 1 (p>0.05). As reported by Ogawa and Maia (1999), the $\mathrm{pH}$ in salmon can range from 6.1 to 6.3. According to the Brazilian legislation, the $\mathrm{pH}$ of fish should be lower than 7.0 to be considered fresh and acceptable for consumption (BRASIL, 2017). All samples of this study were within the limit established by law. From the physicochemical point of view, the $\mathrm{pH}$ value is directly related to the quality and conservation of fish, and the bacterial load is consistent with the variation of $\mathrm{pH}$. Changes in the concentration of hydrogen ions, due to the hydrolytic, oxidative, or fermentative decomposition of the muscle can lead to higher $\mathrm{pH}$ values, thus leading to an increase in the bacterial activity. Fish with a pH below 5.6 has a longer shelf life when compared to those with $\mathrm{pH}$ from 6.2 and 6.6 due to the greater availability of bacterial changes (Ogawa e Maia, 1999; Gonçalves, 2011). 
The hygienic-sanitary quality of the salmon sashimi samples was determined by comparing the microbiological and physicochemical results of each restaurant with national and international standards. Regarding the samples from the restaurant R1, $10 \%$ were unsatisfactory for Enterobacteriaceae, $100 \%$ for thermotolerant coliforms, $1 \%$ exhibited the presence of Salmonella sp. and 6\% Vibrio parahaemolyticus, while in R4, 40\% were unsatisfactory for Enterobacteriaceae and 5\% were contaminated with $V$. parahaemolyticus. The samples from the restaurant R5 were $100 \%$ unsatisfactory for Enterobacteriaceae, $50 \%$ for thermotolerant coliforms and $1 \%$ exhibited the presence of V. parahaemolyticus. Finally, the samples from the restaurants R2 and R3 were $100 \%$ satisfactory (Table 2).

Table 2. Hygienic-sanitary quality of salmon (Salmo salar) sashimi ready for consumption in the city of Cuiaba, Mato Grosso, Brazil

\begin{tabular}{lll}
\hline & Satisfactory & Unsatisfactory \\
\hline R1 & $0 \%$ & $100 \%$ \\
R2 & $100 \%$ & $0 \%$ \\
R3 & $100 \%$ & $0 \%$ \\
R4 & $40 \%$ & $60 \%$ \\
R5 & $0 \%$ & $100 \%$ \\
\hline
\end{tabular}

Source: Authors (2021).

Principal Component Analysis (PCA) was used to synthesize the quantitative results considered as variables, aimed to understand the correlation between variables (Figure 1). The principal components 1 and 2, called Dimension 1 (Dim1) and Dimension 2 (Dim 2), are the main explanations of this statistical tool. The two principal dimensions were responsible for $78.1 \%$ of the total variation on the contamination rate of sashimi, and Dim 1 explained 55.2\% and Dim 2 explained $22.9 \%$.

PCA (Figure 1) showed that both R2 and R3 were clustered together, once both dimensions Dim 1 and Dim 2 decrease together. The restaurants R1 and R4 were located in another group, with an increase in Dim 2 with an increase in Dim 1. The restaurant R5 was located alone, not forming a cluster with the others, and it was more distant from the origin, showing greater discrepancy; while Dim 1 was positive and increasing, dimension Dim 2 was negative and decreasing. 
Figure 1. Results for the Principal Components Analysis of the salmon (Salmo salar) sashimi ready for consumption in the city of Cuiaba, Mato Grosso, Brazil.

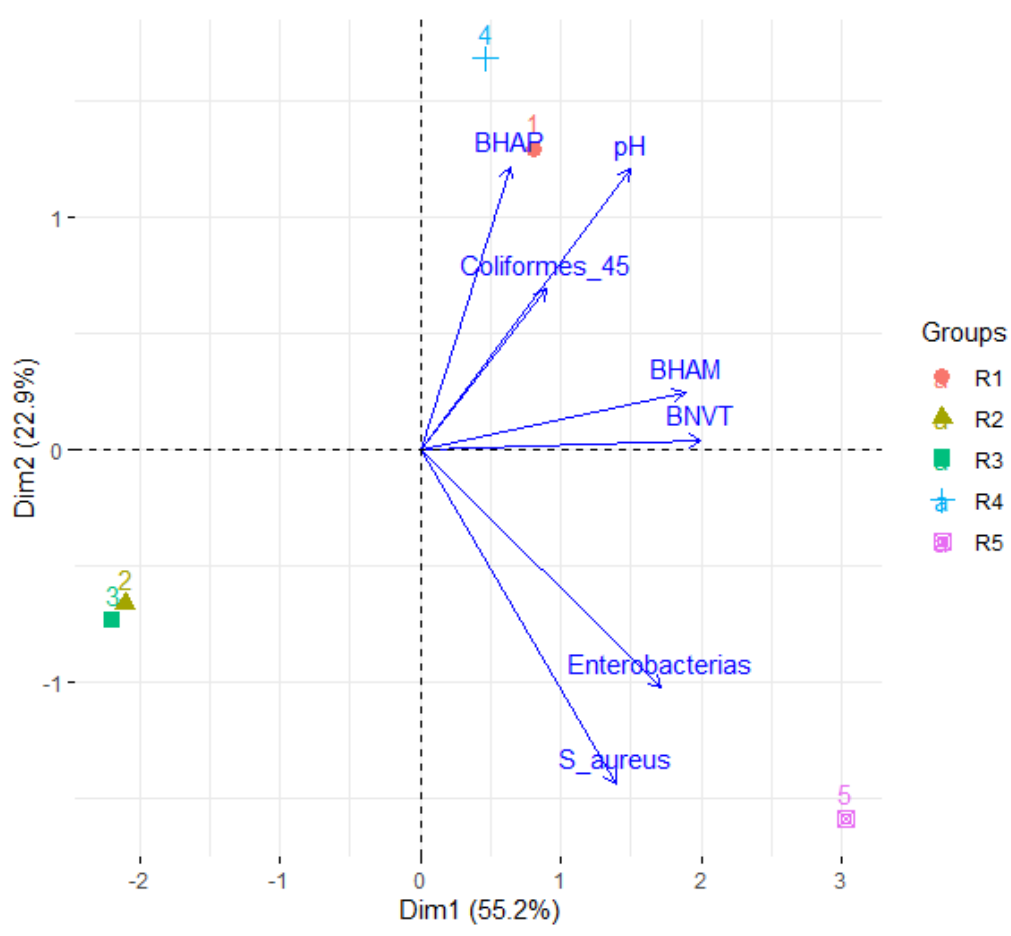

Source: Authors (2021)

For a better interpretation of the graph, the angle between variables was measured (APHB, AMHB, pH, TVB-N, etc). Dim 1 showed a strong positive correlation between the variables TVB-N and AMHB, thus it is possible to state that AMHB increased with an increase in TVB-N, as they formed an acute angle and the vectors had very close sizes. Concerning Dim 2, the variables thermotolerant coliforms, $\mathrm{pH}$, and APHB presented quite strong correlations, as they form acute angles to each other, that is, the increase in $\mathrm{pH}$ was affected by the increase in thermotolerant coliforms, and the APHB growth was the most responsible for increasing the $\mathrm{pH}$. There was a strong correlation between $\mathrm{R} 1$ and $\mathrm{R} 4$ for the variable APHB, with fast growth in R1. A strong correlation between the variables S. aureus and Enterobacteriaceae was observed, with a strong correlation with R5. In contrast, R2 and R3 were located in opposite directions to all variables, indicating a strong negative correlation, that is, there was no interaction between the variables of these restaurants, thus they can be classified as the best quality restaurants according to the PCA, confirming the results of microbiological and physicochemical characterization.

\subsection{Antimicrobial resistance profile}

Antimicrobial susceptibility tests were applied according to the classification of the Clinical and Laboratory Standards Institute (CLSI, 2010, 2016 e 2018), for drugs of first, second, and third choice for the treatment of pathogenic bacteria isolated in this study. The antimicrobial resistance profile is shown in Table 3, for the isolates Vibrio parahaemolyticus $(\mathrm{n}=12$ ) Staphylococcus aureus $(\mathrm{n}=12)$ and Salmonella $\mathrm{sp} .(\mathrm{n}=1)$. 
Table 3. Results of the antibiogram of Vibrio parahaemolyticus, Staphylococcus aureus and Salmonella sp. from salmon (Salmo salar) sashimi ready for consumption in the city of Cuiaba, Mato Grosso, Brazil.

\begin{tabular}{|c|c|c|c|}
\hline & $\begin{array}{l}\text { Resistant } \\
(\%)\end{array}$ & $\begin{array}{ll}\text { N. Intermediate } \\
(\%)\end{array}$ & $\begin{array}{ll}\text { N. } & \text { Sensitive } \\
& \text { N. }(\%) \\
\end{array}$ \\
\hline \multicolumn{4}{|c|}{ V.parahaemolyticus } \\
\hline \multicolumn{4}{|l|}{$\beta$ - lactams } \\
\hline AMP & 11/12 (91.6) & $1 / 12(8.3)$ & $0 / 12$ \\
\hline CTX & $7 / 12(58.3)$ & $1 / 12(8.3)$ & 4/12 (33.3) \\
\hline CFO & $9 / 12(75.0)$ & $1 / 12(8.3)$ & 2/12 (16.6) \\
\hline \multicolumn{4}{|c|}{ Aminoglycoside } \\
\hline GEN & $6 / 12(50.0)$ & $4 / 12(33.3)$ & 2/12 (16.6) \\
\hline AMI & $8 / 12(66.6)$ & $1 / 12(8.3)$ & $(3 / 12(25.0)$ \\
\hline \multicolumn{4}{|l|}{ Tetracycline } \\
\hline TET & $11 / 12(91.6)$ & $1 / 12(8.3)$ & $0 / 12$ \\
\hline \multicolumn{4}{|c|}{ Sulphonamide } \\
\hline TMP-SMX & $3 / 12(25.0)$ & $0 / 12$ & $9 / 12(75.0)$ \\
\hline \multicolumn{4}{|l|}{ S. aureus } \\
\hline \multicolumn{4}{|l|}{$\beta$ - lactams } \\
\hline PEN & $12 / 12(100.0)$ & $0 / 12$ & $0 / 12$ \\
\hline $\mathbf{O X A}^{\mathbf{a}}$ & $7 / 12(58.3)$ & $3 / 12(25.0)$ & 2/12 (16.6) \\
\hline $\mathbf{A M P a}$ & $12 / 12(100.0)$ & $0 / 12$ & $0 / 12$ \\
\hline CTX $^{\mathbf{a}}$ & $3 / 12(25.0)$ & 9/12 (75.0) & $0 / 12$ \\
\hline CFO & $10 / 12(83.3)$ & 2/12 (16.6) & $0 / 12$ \\
\hline \multicolumn{4}{|c|}{ Aminoglycoside } \\
\hline GEN & $7 / 12(58.3)$ & $3 / 12(25.0)$ & 2/12 (16.6) \\
\hline $\mathbf{A M I}^{\mathbf{b}}$ & $10 / 12(83.3)$ & 2/12 (16.6) & $0 / 12$ \\
\hline \multicolumn{4}{|l|}{ Tetracycline } \\
\hline TET & $7 / 12(58.3)$ & $5 / 12(41.6)$ & $0 / 12$ \\
\hline \multicolumn{4}{|c|}{ Sulphonamide } \\
\hline TMP-SMX & $0 / 12$ & $0 / 12$ & $12 / 12(100.0)$ \\
\hline \multicolumn{4}{|c|}{ Salmonella sp. } \\
\hline \multicolumn{4}{|l|}{$\beta$ - lactams } \\
\hline AMP & 0 & 0 & $1(100 \%)$ \\
\hline CTX & 0 & $1(100 \%)$ & 0 \\
\hline CFO & 0 & 0 & $1(100 \%)$ \\
\hline \multicolumn{4}{|c|}{ Aminoglycoside } \\
\hline GEN & 0 & 0 & $1(100 \%)$ \\
\hline AMI & 0 & $1(100 \%)$ & 0 \\
\hline \multicolumn{4}{|l|}{ Tetracycline } \\
\hline TET & 0 & $1(100 \%)$ & 0 \\
\hline \multicolumn{4}{|c|}{ Sulphonamide } \\
\hline TMP-SMX & 0 & 0 & $1(100 \%)$ \\
\hline
\end{tabular}

a: according to M100-S21 CLSI (2011); b: according to M100-S26 CLSI (2016). Source: Authors (2021)

Twelve S. aureus isolates were identified, as follows: R2 $(\mathrm{n}=1), \mathrm{R} 3(\mathrm{n}=3), \mathrm{R} 4(\mathrm{n}=1)$, and R5 $(\mathrm{n}=7)$. The isolates showed $100 \%$ resistance to Penicillin and Ampicillin, $83.3 \%$ resistance to Cefoxitin and Amikacin, 58.3\% resistance to Oxacillin, Gentamicin, and Tetracycline. The lowest resistance was observed for Cefotaxime, with 25\%, while Trimethropim- 
sulfamethoxazole was the most sensitive antimicrobial agent for $100 \%$ of isolates (Table 3). Given the results, the antibiotic Trimethropim-sulfamethoxazole can be an effective alternative for the treatment of $S$. aureus, as the bacteria was sensitive to this antibiotic, probably due to the synergistic combination between Sulfamethoxazole and Trimethoprim, which may have impaired the appearance of resistant strains, with a positive classification for first-choice antibiotics (CLSI, 2018). S. aureus has been widely studied for antibiotic resistance, and high percentages have been found for multiple drugs. Some authors have reported lower and similar results in fresh marine fish in Iran (Arfatahery et al., 2016) when compared to this study, for Penicillin (91.9\% resistance), Ampicillin (89.1\% resistance), and Tetracycline (46\% resistance), while other authors reported $60 \%$ resistance for Tetracycline in Malaysia (Puah, Chua e Tan, 2016). Other studies found low resistance levels to other antimicrobial agents, such as sushi in Denmark (Li et al. 2019), sashimi made with various fish species in Portugal (Moura et al., 2017), imported fish in Switzerland (Boss et al., 2016), and anchovies, trout, and sea bream in Turkey (Onmaz et al., 2015). Moura et al. (2017) reported a higher resistance profile for sashimi made with tuna and sea bass $(44.6 \%$ and $43.1 \%)$, and a lower resistance for salmon (36.9\%) and other fish species (35.4\%).

The Salmonella sp. strains $(\mathrm{R} 1, \mathrm{n}=1)$ isolated in this study showed no resistance to all the antimicrobial agents tested. It presented intermediate resistance to Cefotaxime, Amikacin, and Tetracycline, and was sensitive to Ampicillin, Cefoxitin, Gentamicin, and Trimethropim-sulfamethoxazole, as shown in Table 3. Recent studies in various countries have reported high resistance profile of fresh fish to these antimicrobial agents, such as fresh shrimp (Penicillin 100\%, Ampicillin 83.86\%, and Tetracycline 45.45\%) in Nigeria (BESHIRU et al., 2019); fresh prawn (Ampicillin 21.9\%, Tetracycline 25\%, and Trimethropim-sulfamethoxazole 15\%) in Vietnam (Nguyen et al., 2016); fresh marine fish (Ampicillin 44.8\%) in Jordan (Obdait e Salman, 2017); and anchovies and fresh trout (TMP-SMX and GEN 20\%) in Turkey (Onmaz et al., 2015). Knowledge about the sensitivity of Salmonella isolates to the antimicrobial agents used in this study is important for public health, as it allows the use of these agents in therapies during outbreaks since Salmonella outbreaks have been reported as the first causes of ATD in Brazil and in the world (Brasil, 2019; WHO, 2018).

Vibrio parahaemolyticus isolates were found in twelve samples, as follows: R1 $(\mathrm{n}=6), \mathrm{R} 4(\mathrm{n}=5)$, and R5 ( $\mathrm{n}=1)$. The present results indicated resistance to Ampicillin and Tetracycline (91.6\%), Cefoxitin (75\%), Amikacin (66.6\%), Cefotaxime (58.3\%), and Sulfazotrim (25\%), with a great sensitivity observed for Sulfazotrim (75\%), as shown in Table 3. Although the $V$. parahaemolyticus isolates were resistant to all the antimicrobials used, better results were observed for Trimethropim-sulfamethoxazole, with sensitivity for the isolates from two restaurants (R4 and R5). According to CLSI (2010), Halophilic Vibrio sp. is normally resistant to sulfonamides, penicillins, and other cellelaphosporins. In this study, resistance to aminoglycosides (Amikacin, Gentamicin), Tetracycline, and semi-synthetic penicillin (Ampicillin) was also observed.

The microorganism $V$. parahaemolyticus is frequently associated with diseases transmitted by seafood, being of concern in fish, mollusks, shrimp and consequently to human health, due to its multi antimicrobial resistance. This microorganism has shown higher resistance rates to Ampicillin (91\%), demonstrating the ineffective action of this antibiotic, not being an alternative to combat this species, as also reported by some authors in Korea (Ryu et al., 2019; Kang et al., 2018), Brasil (Silva et al., 2018), Poland (Lopatek et al., 2018), Vietnam (Vu et al., 2016), China (Xu et al., 2016) e no Ecuador (Sperling et al., 2015). Studies have shown that Tetracycline, which exhibited $91 \%$ resistance in this study, presented great sensitivity for these bacteria in Korea, Brazil, Poland, and China. Cefotaxime, defined as a first-choice drug by CLSI (2010), showed a significant resistance $(58.3 \%)$, indicating low in vitro activity. Some authors have also reported a strong sensitivity to Trimethropim-sulfamethoxazole, as observed in the present study (Millanao et al., 2018; Cabello e Godfrey, 2016).

In general, several factors are correlated with increased resistance of antimicrobials, such as overuse in aquaculture (XU et al., 2016) and genetically modified organisms in the aquatic environment. Although some antimicrobial agents behave 
similarly for different marine fish and seafood species, such comparison is still difficult, due to the different origin, the collection procedures, and the methodologies used, as observed by Lopatek et al. (2018).

\section{Conclusion}

It was concluded that $48 \%$ of sashimi samples were suitable for human consumption, while $52 \%$ presented unsatisfactory hygienic-sanitary quality for the parameters evaluated, which can be a risk to the consumers' health, such as the development of a Foodborne Disease (FBD). The restaurants R2 and R3 presented better hygienic-sanitary conditions when compared to R1, R4, and R5.

The antimicrobial resistance profile revealed that both the $S$. aureus and $V$. parahaemolyticus isolates showed sensitivity in vitro only to Trimethropim-sulfamethoxazole, which is a challenge related to the guidelines to assist with treatment choices in the case of foodborne illness.

Based on this study, it is suggested that similar work be carried out in several cities in the country for a broader survey of the quality of this food matrix, as well as scientific studies related to handling and raw materials.

\section{Acknowledgments}

To the IFMT for the bench fee for conducting the research and to the Foundation for Research Support of the State of Mato Grosso (FAPEMAT) for granting the scholarship.

\section{References}

Arfatahery, N., Davoodabadi, A., \& Abedimohtasab, T. (2016). Characterization of Toxin Genes and Antimicrobial Susceptibility of Staphylococcus aureus Isolates in Fishery Products in Iran. Scientific Reports. 6:34216. https://doi.org/10.1038/srep34216

Bauer, A. W., Kirby, W. M. M., Sherris, J. C., \& Turck, M. (1966) Antibiotic susceptibility testing by a standardized single disk method. American Journal of Clinical Pathology. 45: 493-496. https://doi.org/10.1093/ajcp/45.4_ts.493

Beshiru, A., Igbisona, I. H., \& Igbnosa, E. O. (2019). Prevalence of Antimicrobial Resistance and Virulence Gene Elements of Salmonella Serovars From Ready-to-eat (RTE) Shrimps. Frontiers in Microbiology. 10:1613. https://doi.org/10.3389/fmicb.2019.01613

Boss, R., Overesch, G., \& Baumgartner, A. (2016). Antimicrobial Resistance of Escherichia coli, Enterococci, Pseudomonas aeruginosa, and Staphylococcus aureus from Raw Fish and Seafood Imported into Switzerland. Journal of Food Protection. 79:7:1240-1246. https://doi.org/10.4315/0362-028X.JFP-15-463

Brasil. Ministry of Agriculture. (1981). Official analytical methods for controlling animal products and their ingredients: II - Physical and chemical methods. National Secretariat for Agricultural Defense; National Animal Reference Laboratory, Brasilia DF.

Brasil. National Health Surveillance Agency. Resolution RDC 12 of January 2, 2001 (2001). which approves the Technical Regulation on Microbiological Standards for Food, Gazeta Oficial da Uniáo. Brasília - DF.

Brasil. Ministry of Agriculture, Livestock, and Supply. Decree 9,013, of March 29, 2017 on the Regulation of industrial and sanitary inspection of products of animal origin; Presidency of the Republic, Casa Civil, 2017; Brasília-DF.

Brasil. MS/SVS. (2019). Ministry of Health, Health Surveillance Secretariat; Foodborne Disease Outbreaks: Report 2018. http://portalarquivos2.saude.gov.br/images/pdf/2019/maio/17/Apresentacao-Surtos-DTA-Maio- 2019.pdf;

Cabello, F. C.; \& Godfrey, H. P. (2016). Even therapeutic antimicrobial use in animal husbandry may generate environmental hazards to human health. Environmental Microbiology. 18: 311-313. https://doi.org/10.1111 / 1462-2920.13247

Cabello, F. C., Godfrey, H. P, Buschmann, A. H., \& Dölz, H. J. (2016). Aquaculture as yet another environmental gateway to the development and globalization of antimicrobial resistance. Lancet Infectious Diseases. 16:7: 127-133. https://doi.org/10.1016 / S1473-3099 (16) 00100-6

CLSI. Clinical and Laboratory Standards Institute. (2010). Methods for Antimicrobial Dilution and Disk Susceptibility Testing of Infrequently Isolated or Fastidious Bacteria. Approved Guideline 2th ed. 2010; Document M45-A2. Wayne, PA, EE.UU.

CLSI. Clinical and Laboratory Standards Institute. (2016). Performance Standards for Antimicrobial Susceptibility Testing. 26th ed. 2016; supplement M100S. Wayne, PA, EE.UU.

CLSI. Clinical and Laboratory Standards Institute. (2018). Performance Standards for Antimicrobial Susceptibility Testing. 28th ed. 2018; supplement M100. Wayne, PA, EE.UU. 
CFS. Centre for Food Safety. (2019). Microbiological Guidelines for Food For ready-to-eat food in general and specific food itens, 2014; Hong Kong, CN. https://www.cfs.gov.hk/english/index.html; accessed in 10/09/2019.

European Communities. (1995). Commission decision fixing the total volatile basic nitrogen (TVB-N) values for certain categories of fishery products and specifying the analysis methods to be used 95/149 / EC. Official Journal of the European Communities. L97: 84-87.

FAO. Food and Agriculture Organization of the United Nations. Section 2 - Recommended International Code of Practice - General Principles of Food Hygiene. In: 17. FAO. Food and Agriculture Organization of the United Nations. Food Quality and Safety Systems - A Training Manual on Food Hygiene and the Hazard Analysis and Critical Control Point (HACCP) System.1998. http://www.fao.org/docrep/W8088E/w8088e04.htm accessed in 01/15/2020.

FDA. Food and Drug Administration. (2012). Bad Bug Book, Foodborne Pathogenic Microorganisms and Natural Toxins: Vibrio parahaemolyticus, 2th ed. 2012; 2:26-29. https://www.fda.gov/downloads/Food/FoodborneIllnessContaminants/UCM297627.pdf.

Gonçalves, A. A. (2011). Fish Technology: Science, Technology, Innovation and Legislation, 1th ed. São Paulo: Editora Atheneu, p.624.

Howgate, P. (2010). A critical review of total volatile bases and trimethylamine as índices of freshness of fish; Part.1: Determination, Electronics Journal of Environmental, Agricultural and Food Chemistry. 9:1 29-57.

ICMSF. International Commission on Microbiological Specifications for foods. (1986). 2. Sampling for microbiological analysis: principles and specific applications. 2th ed. London: Blackwell Scientific Publications. 1986; p.131.

ISO. International Organization for Standardization. (1999). Meat and meat products, measurement of pH, Reference method 2th ed. (ISO 2917). Geneva, SWI.

Kang, C. H., Shin, Y., Yu, H., Kim, S., \& So, J. S. (2018). Antibiotic and heavy-metal resistance of Vibrio parahaemolyticus isolated from oysters in Korea. Marine Pollution Bulletin. 135: 69-74. https://doi.org/10.1016/j.marpolbul.2018.07.007

Kim, H. W., Hong, Y. J., Jo, J.I., Ha, S. D., Kim, S. H., Lee, H. J., \& Rhee, M. S. (2016). Raw ready-to-eat seafood safety: microbiological quality of the various seafood species available in fishery, hyper and online markets. Letters in Applied Microbiology. 64: 27-34. https://doi.org/10.1111/lam.12688

Lanzarin, M., Almeida Filho, E. S., Ritter, D. O., Mello, C. A., Corrêa, G. S. S., \& Ignácio, C. M. S. (2011). Occurrence of Aeromonas sp. and psychrotrophic microorganisms and estimated shelf life of Pintado (Pseudoplatystoma coruscans) fillet kept refrigerated. Brazilian Archives of Veterinary Medicine and Animal Science. 63:6: 1541-1546. https://doi.org/10.1590/S0102-09352011000600035

Li, H., Stegger, M., Dalsgaard, A., \& Leisner, J. J. (2019). Bacterial content and characterization of antibiotic resistant Staphylococcus aureus in Danish sushi products and association with food inspector rankings. International Journal of Food Microbiology. 305:108244. https://doi.org/10.1016/j.ijfoodmicro.2019.108244.

Liang, W. L., Pan, Y. L., Cheng, H. L., Li, T. C., Yu, P. H. F., \& Chan, S. W. (2016). The microbiological quality of take-away raw salmon finger sushi sold in Hong Kong. Food Control. 69: 45-50. https://doi.org/10.1016/j.foodcont.2016.04.015.

Lopatek, M., Wieczorek, K., \& Osek, J. (2018). Antimicrobial Resistance, Virulence Factors, and Genetic Profiles of Vibrio parahaemolyticus from Seafood. Applied and Environmental Microbiology. 84:16: 1-10. https://doi.org/10.1128/ AEM.00537-18.

Miguéis, S., Moura, A. T., Saraiva, C., \& Esteves, A. (2016). Influence of season and type of restaurants on sashimi microbiota. The European Journal of Public Health. 26:5: 877-881. https://doi.org/10.1093/eurpub/ckw009

Miguéis, S., Santos, C., Saraiva, C., \& Esteves, A. (2015). Evaluation of ready to eat sashimi in northern Portugal restaurants. Food Control. 47:32-36. https://doi.org/10.1016/j.foodcont.2014.06.025

Millanao, A. R., Barrientos-Schaffeld, C., Siegel-Tike, C. D., Ivanova, L., Godfrey, H. P., Dolz, H. J., Buschmann, A. H., \& Cabello, F. C. (2018). Resistance to antimicrobials in Chile and the Una Salud paradigm: managing risks for human and animal public health resulting from the use of antimicrobials in salmon aquaculture and medicine. Chilean Journal of Infectology. 35:3: 299-303. https://doi.org/10.4067/s0716-10182018000300299.

Moura, A. T. ; Saraiva, C., Miguéis, S., Esteves, A. \& Fontes, M. C. (2017). Antimicrobial Susceptibility of Coagulase-Positive and Coagulase-Negative Staphylococci in Ready-to-Eat Sashimi. Journal of Aquatic Food Product Technology. 26:1: 95-102. https://doi.org/10.1080/10498850.2015.1099069

Muscolino, D., Giarratana, F., Beninati, C., Tornambene, A., Panebianco, A., \& Ziino, G. (2014). Hygienic-sanitary evaluation os sushi and sashimi sold in Messina ans Catania, Italy. Italian Journal of Food Safety. 3:1701: 134-136. https://doi.org/10.4081 / ijfs.2014.1701.

Nguyen, D. T., Kanki, H., Nguyen, D. P., Le, H. T., Ngo, P. T., Tran, D. N., Le, N. H., Dang, C. Y., Kawai, T., Kawahara, R., Yonogi, S., Hirai, Y., Jinnai, M., Yamasaki, S., Kumeda, Y., \& Yamamoto, Y. (2016). Prevalence, antibiotic resistance, and extended-spectrum and AmpC $\beta$-lactamase productivity of Salmonella isolates from raw meat and seafood samples in Ho Chi Minh City, Vietnam. International Journal of Food Microbiology. 236:7: 115-12. https://doi.org/10.1016/j.ijfoodmicro.2016.07.017.

Nollet, I. M. L., \& Toldrá, F. (2010). Handbook of seafood and seafoos products analysis. CRC Press - Taylor \& Francis Group. Boca Raton, FL. p.910.

Obdait, M. M., \& Salman, A. E. B. (2017). Antimicrobial Resistance Percentages of Salmonella and Shigella in Seafood Imported to Jordan: Higher Percentages and More Diverse Profiles in Shigella. Journal of Food Protection. 80:3: 414-419. https://doi.org/10.4315/0362-028X.JFP-16-322

Ogawa, M., \& Maia, E.L. (1999). Fishing manual: science and technology of fish. 1ed. São Paulo: Varela. p. 430.

Onmaz, E. N., Abay, S., Karadal, F., Hizlisoy, H., Telli, N., \& Al, S. (2015). Occurence and antimicrobial resistance of Staphylococcus aureus and Salmonella spp. in retail fish samples in Turkey. Marine Pollution Bulletin. 90: 242-246. https://doi.org/10.1016/j.marpolbul.2014.10.0460025-326X. 
Pereira, A. S., Shitsuka, D. M., Parreira, F. J., \& Shitsuka, R. (2018). Metodologia da pesquisa cientifica. UFSM. https://repositorio.ufsm.br/bit stream/handle/1/1 582 4/Lic_Computacao_Metodologia-Pesquisa-Cientifica.pdf?sequence=1

Puah, S. M., Chua, K. H., \& Tan, J. A. M. A. (2017). Prevalence of Staphylococcus aureus and Salmonella enterica in ready-to-eat sushi and sashimi. Tropical Biomedicine. 34(1): 45-51. ISSN: 0127-5720. http://www.myjurnal.my/public/article-view.php?id=111609 accessed in 10/19/2019.

Puah, S. M., Chua, K. H., \& Tan, J. A. M. A. (2016). Virulence Factors and Antibiotic Susceptibility of Staphylococcus aureus Isolates in Ready-to-Eat Foods: Detection of S. aureus Contamination and a High Prevalence of Virulence Genes. International Journal of Environmental Research and Public Health. 13:2: 199. https://doi.org/10.3390/ijerph13020199.

R Core Team. R: A language and environment for statistical computing. R Foundation for Statistical Computing, 2019; Vienna, Austria. https://www.Rproject.org/ accessed in 10/19/2019.

Ryser, E. T., \& Schuman, J. D. (2015). Mesophilic Aerobic Plate Count in: SALFINGER Y. \& TORTORELLO ML. (eds.), Compendium of Methods for the MicrobioLogical Examination of Foods, 5th ed. American Public Health Association. Washington, D.C., Chapter 8, p.95-101.

Ryu, A. R., Mok, J. S., Lee, D. E., Kwon, J. Y., \& Park, K. (2019). Occurrence, virulence, and antimicrobial resistance of Vibrio parahaemolyticus isolated from bivalve shellfish farms along the southern coast of Korea. Environmental Science and Pollution Research 26:21034-21043. https://doi.org/10.1007/s11356-019-05426-1.

Sakazaki, R. (2003). Vibrio parahaemolyticus. Encyclopedia of Food Sciences and Nutrition (Second Edition); p. 5988.

Silva, I. P., Carneiro, C. Z., Saraiva, M. A. F., Oliveira, T. A. S., Sousa, O. V., \& Evangelista-Barreto, N. S. (2018). Antimicrobial resistance and potential virulence of Vibrio parahaemolyticus isolated from water and bivalve mollusks from Bahia, Brazil. Marine Pollution Bulletin. 131: 757-762. https://doi.org/10.1016/j.marpolbul.2018.05.007

Silva, N., Junqueira, V. C. A., Silveira, N. F. A., Taniwaki, M. H., Gomes, R. A. R., \& Okazaki, M. M. (2017). Manual of methods of microbiological analysis of food and water; $5^{\text {th }}$ ed., São Paulo: Blucher, 560p. ISBN: 978-85-212-1225-6.

Sperling, L., Alter, T., \& Huehn, S. (2015). Prevalence and Antimicrobial Resistance of Vibrio spp. in Retail and Farm Shrimps in Ecuador. Journal of Food Protection. 78:11: 2089-2092. https://doi.org/10.4315/0362-028X.JFP-15-160

Venter, H., Henningsen, M. L., \& Begg, S. L. (2017). Antimicrobial resistance in healthcare, agriculture and the environment: the biochemistry behind the headlines. Essays Biochem. 61: 1-10. https://doi.org/10.1042 / EBC20160053

Vu, T. T. T., Lu, M., Pichpol, D., Pham, N. H., Baumann, M., Alter, T., \& Huehn, S. (2016). Prevalence and antimicrobial resistance of Vibrio spp. in retail shrimps in Vietnam: Prävalenz und antimikrobielle Resistenz von Vibrio spp. in Shrimps von Märkten in Vietnam. Berliner und Münchener tierärztliche Wochenschrift. 129:1: 48-51. ISSN: 0005-9366. https://doi.org/10.2376 / 0005-9366-129-48

Xu, X., Cheng, J., Wu, Q., Zhang, J., \& Xie, T. (2016). Prevalence, characterization, and antibiotic susceptibility of Vibrio parahaemolyticus isolated from retail aquatic products in North China. BioMed Central Microbiology. 16:32. https://doi.org/10.1186/s12866-016-0650-6

WHO. World Health Organization. (2012). Animal Waste, Water Quality and Human Health. London: WHO/ IWA, 489p. ISBN: 9781780401232.

WHO. World Health Organization. (2019). Salmonella (non-thyphoidal). https://www.who.int/news-room/fact-sheets/detail/salmonella-(non-typhoidal); accessed in: 10/18/2019. 